\title{
STUDIES ON THE EFFECTS OF QUININ ON THE LIVER, BLOOD CELLS AND URINE OF RABBITS *
}

\author{
DAVID M. SIPERSTEIN AND MORRIS LITMAN \\ MINNEAPOLIS \\ I. EFFECT OF QUININ ON THE LIVER
}

In the course of a series of observations on the excretion of bile pigments in the duodenum following the use of quinin, Prof, J. P. Schneider ${ }^{1}$ found that the bile pigments of the duodenal contents were markedly increased and that urobilinogen also appeared. He regarded this as an indication that the drug gave rise to pathologic changes in the liver. In a search of the literature we have been unable to find reference to any studies on the effect of quinin on the structure of the liver. The present investigation was, therefore, undertaken at his suggestion to determine whether pathologic changes in the liver could be induced in rabbits by the administration of doses of quinin comparable to those given in clinical practice or whether the drug gave rise to hemolysis in vivo.

\section{MATERIAL AND METHODS}

For the present investigation, fifteen healthy rabbits were used. Two of them died as a result of the injections and were discarded. With two exceptions, a 2 per cent. solution of quinin hydrochlorid in a Ringer-Langendorf mixture was used. All injections were made intravenously to assure a greater degree of accuracy.

The rabbits were killed by a blow on the head with a heavy stick. The abdomen was immediately opened and pieces of liver tissue snipped off and allowed to drop into a beaker containing a 10 per cent dilution of liquor formaldehydi solution or Carnoy's fluid No. 1. Paraffin sections, cut at 10 microns, were stained with hematoxylin and eosin, and studied. All the material was treated exactly alike.

\section{PROTOCOLS}

RabBit 1 (Fig. 1).-Weight. 1,950 gm.; received ro quinin; killed as a control. Normal arrangement of liver cells in cords. Cytoplasm is finely granular, no vacuoles. Pigment granules abundant in liver cells.

RABBIT 2.-Weight, 1,850 gm.; received no quinin; killed as a control. Same as Rabbit 1 .

* From the Department of Pharmacology, University of Minnesota.

1. Schneider, J. P.: J. A. M. A. 74:1759 (June 26) 1920. 
Rabeit 3 (Fig. 2).-Weight, $1,680 \mathrm{gm}$; received $0.13 \mathrm{gm}$. quinin $(0.079 \mathrm{gm}$. per kilo); killed one-half hour after injection. Cords of liver cells greatly narrowed, due apparently to pressure of dilated sinusoids. Sinusoids dilated and filled with corpuscles. No pigment granules in liver cells.

R.ABBIr 4 (Fig. 3).-Weight, $1,850 \mathrm{gm}$; received $0.06 \mathrm{gm}$. of quinin $(0.037$ gm. per kilo); killed twenty-four hours after injection. Normal arrangement of liver cells. Very little pigment in liver cells. Bile capillaries hard to find. Vacuoles present in the cytoplasm of many cells (hydropic degeneration?).

RaBBit 5.-Weight, $2,260 \mathrm{gm}$; received $0.18 \mathrm{gm}$. quinin ( $0.079 \mathrm{gm}$. per kilo); killed twenty-four hours after injection. Liver cells show normal arrangement. Cytoplasm densely granular with small vacuoles. No pigment in hepatic cells.

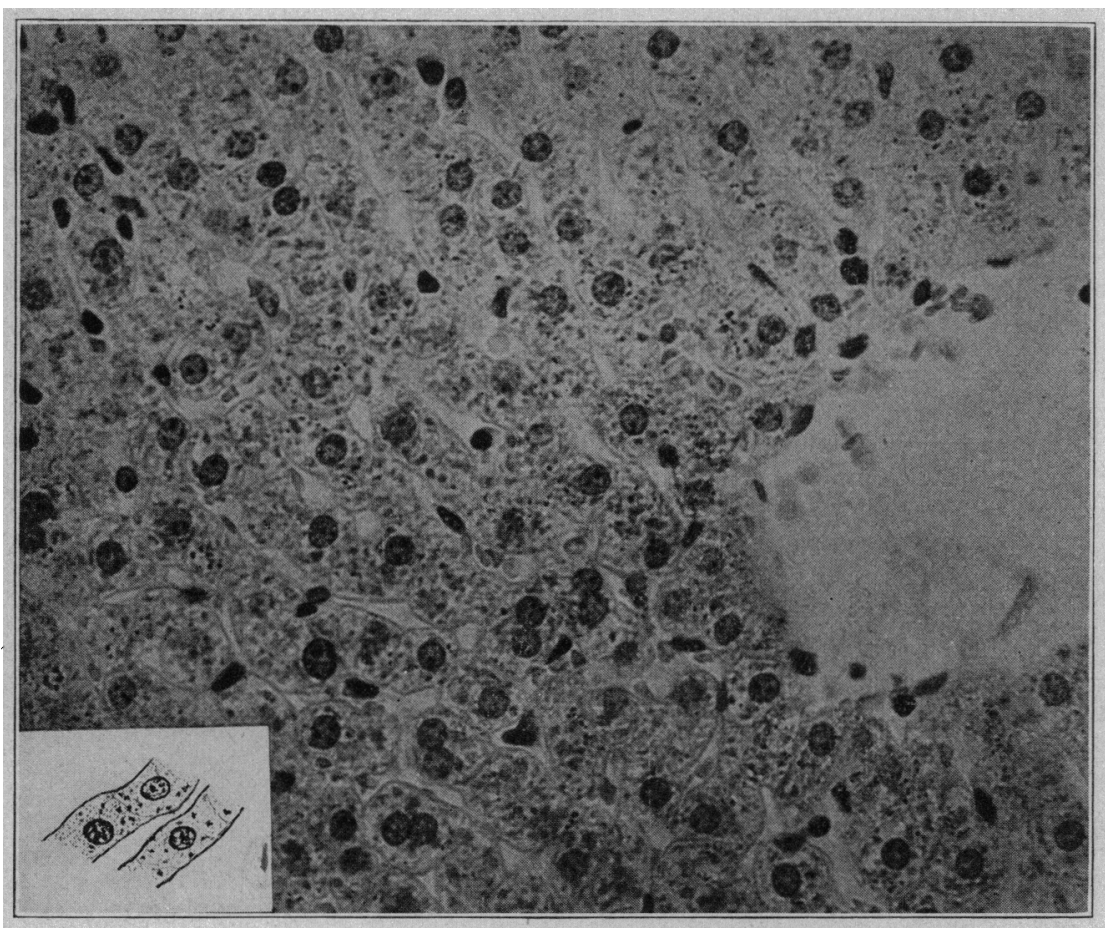

Fig. 1 (Rabhit 1).-Section of normal liver, showing normal structure of cells.

RABBIT 6 (Fig. 4).-Weight, $2,140 \mathrm{gm}$.; received $0.06 \mathrm{gm}$. quinin $(0.028 \mathrm{gm}$. per kilo); killed forty-eight hours after injection. Cytoplasm finely granular containing vacuoles of various sizes (fatty vacuoles). Some bile pigment in liver cells.

Rabit 7 (Fig. 5).-Weight. $1,860 \mathrm{gm}$.; received $0.07 \mathrm{gm}$. quinin $(0.037 \mathrm{gm}$. per kilo): killed ninety-six hours after injection. Normal arrangement of cells. Cytoplasm coarsely granular, no vacuoles. Pigment granules abundant in liver cells.

RabBit 8 (Fig. 6).-Weight, $1.800 \mathrm{gm}$; received $0.14 \mathrm{gm}$. quinin $(0.077 \mathrm{gm}$. per kilo): killed twenty-four hours after injection. Cells have lost their cordlike arrangement. Enlarged liver cells, from three to four times normal in size. Cytoplasm, coarse granules packed at the periphery of cells. Clumps of 


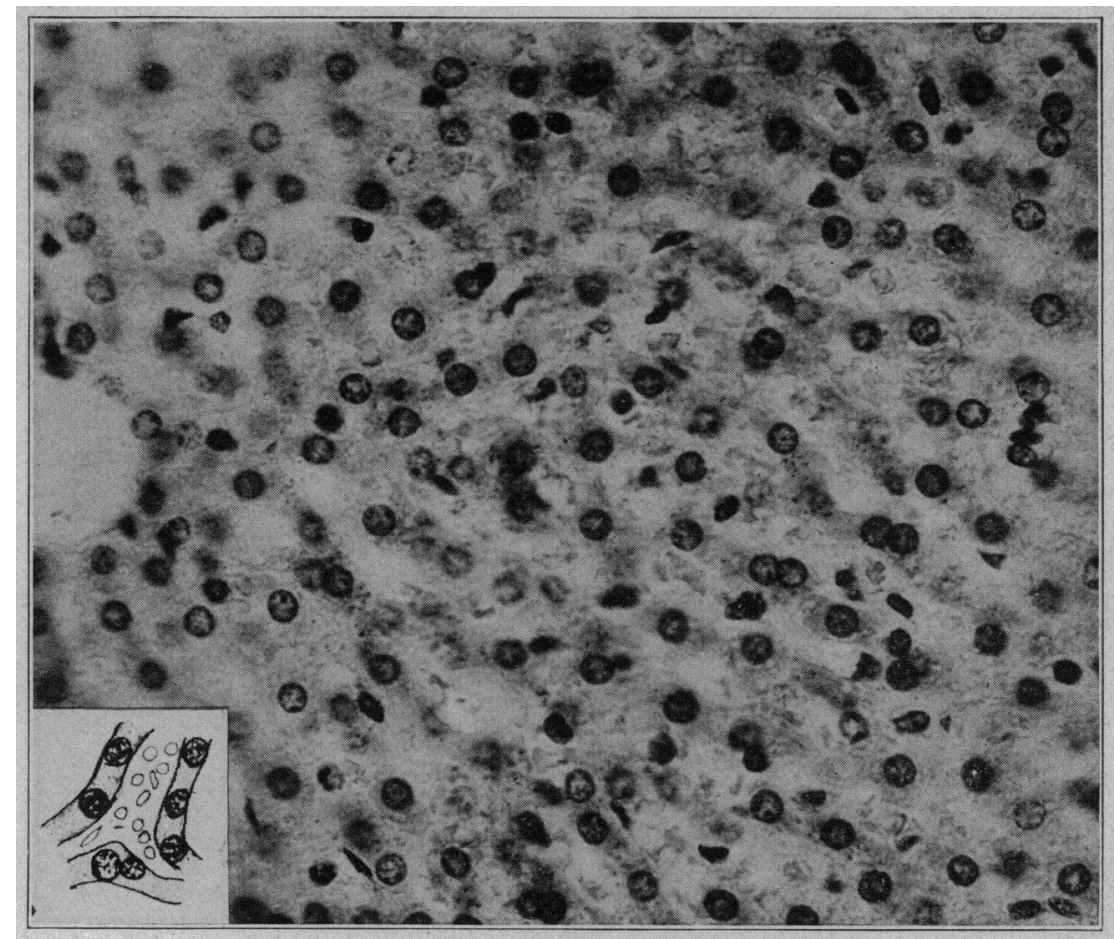

Fig. 2 (Rahbit 3).-Wection showing dilated sinusoids and narrowed cords of liver cells.

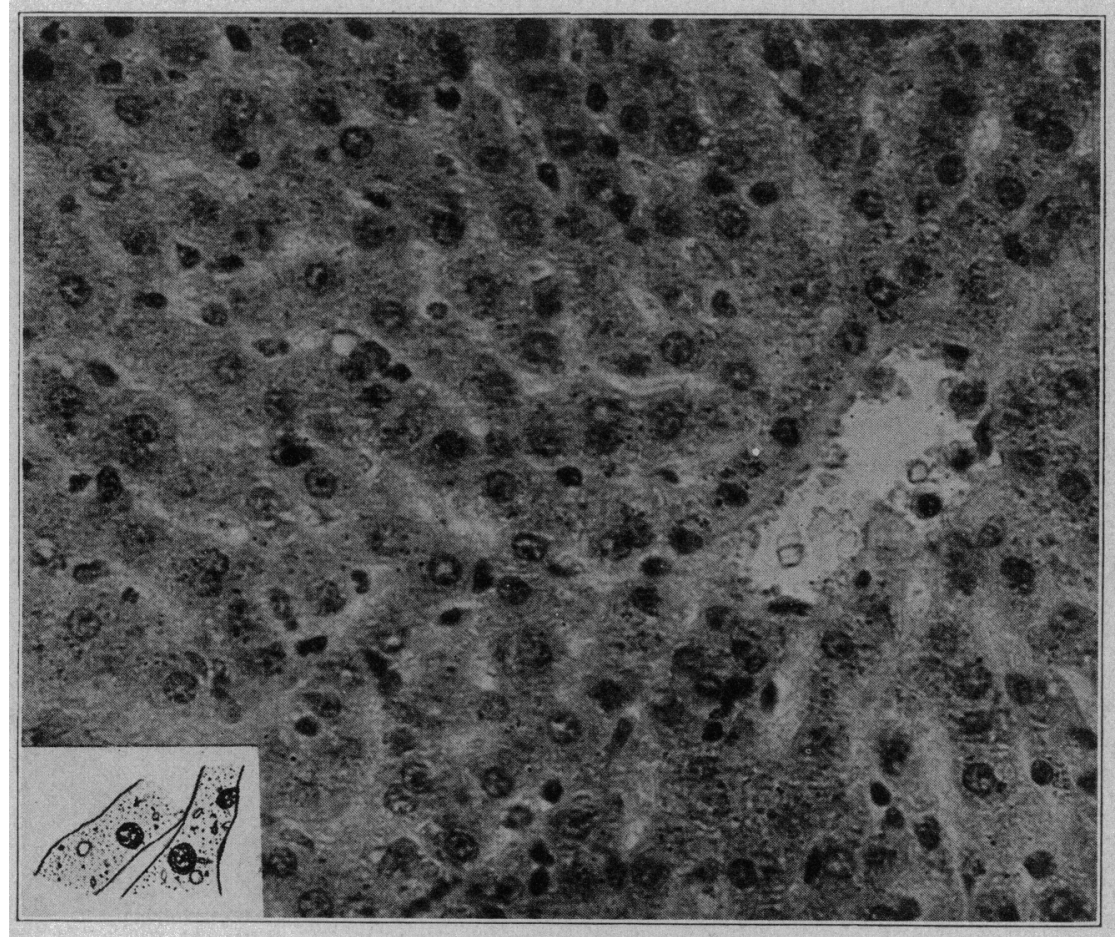

Fig. 3 (Rabhit 4).-Section showing vacuoles in the cytoplasm of many cells (hydropic degeneration?). 


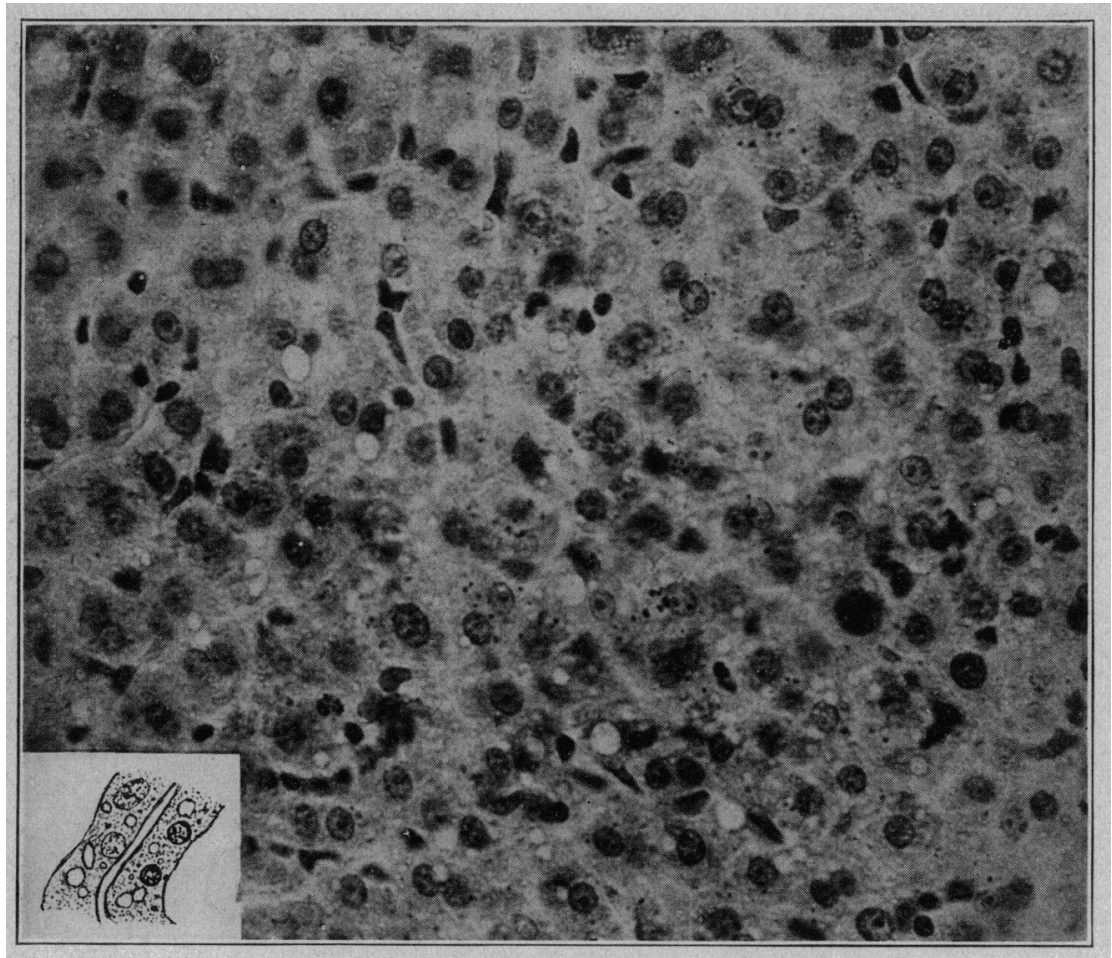

Fig. + (Rablit 6).--Section showing tinely granular cytoplasm containing vacuoles of various sizes (fatty vacuoles?).

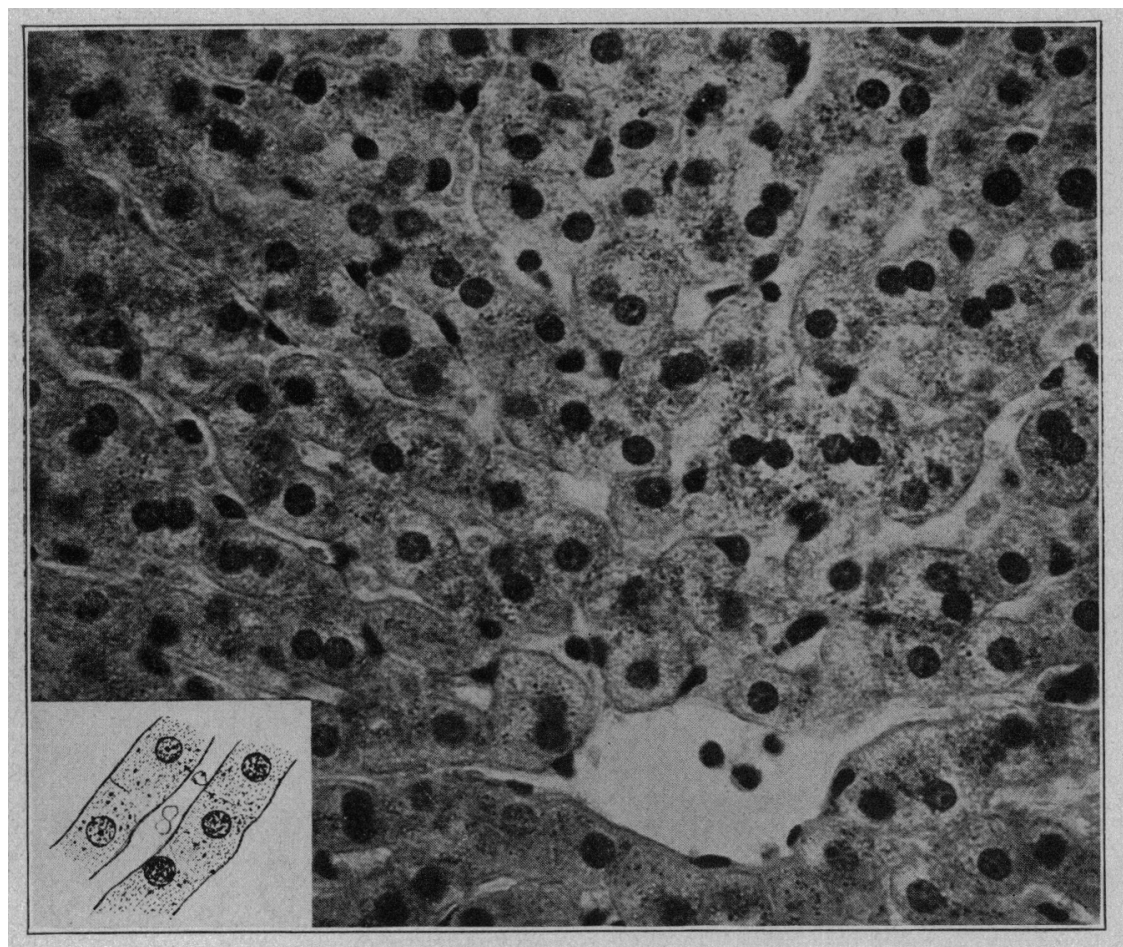

Fig. 5 (Rabloit 7 ).- Section showing liver cells returned to normal. 


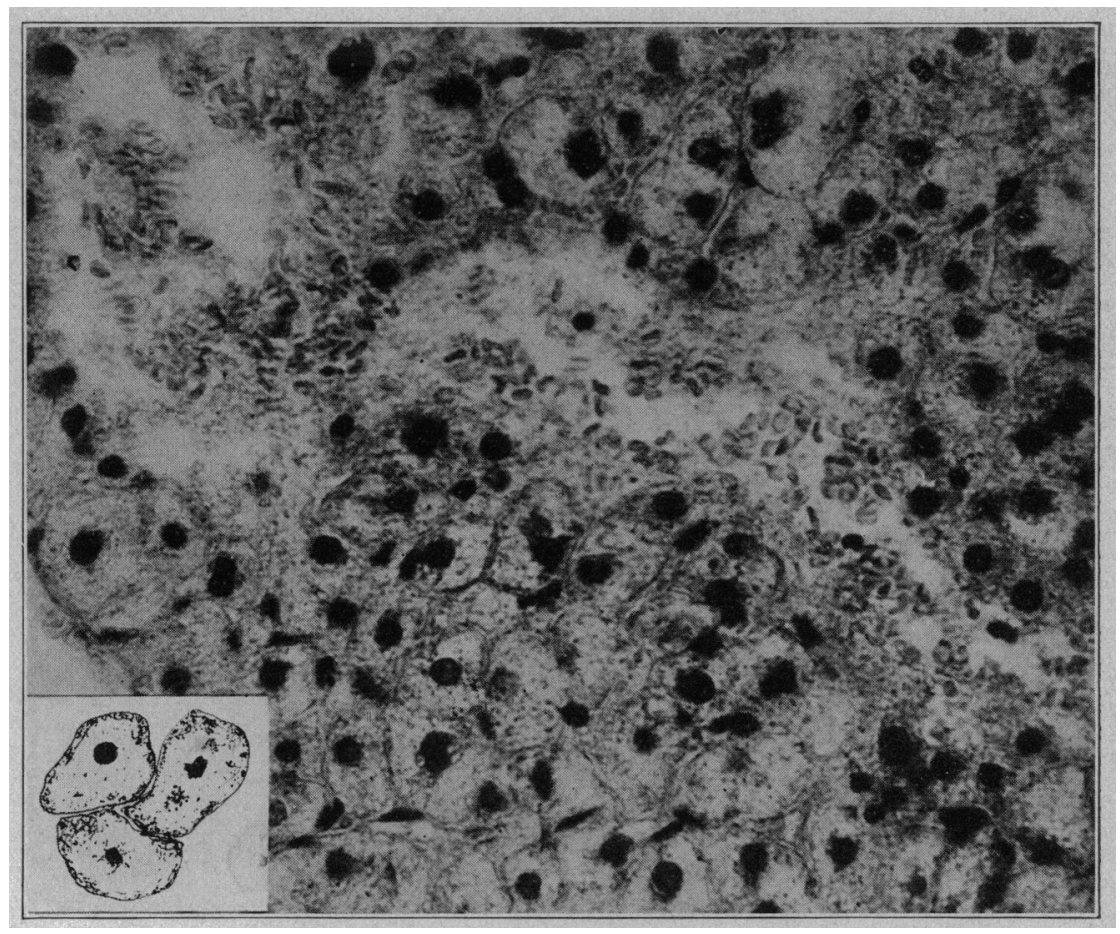

Fig. 6 (Rabbit 8).-Section showing extreme degenerative changes in the cytoplitism of the cells.

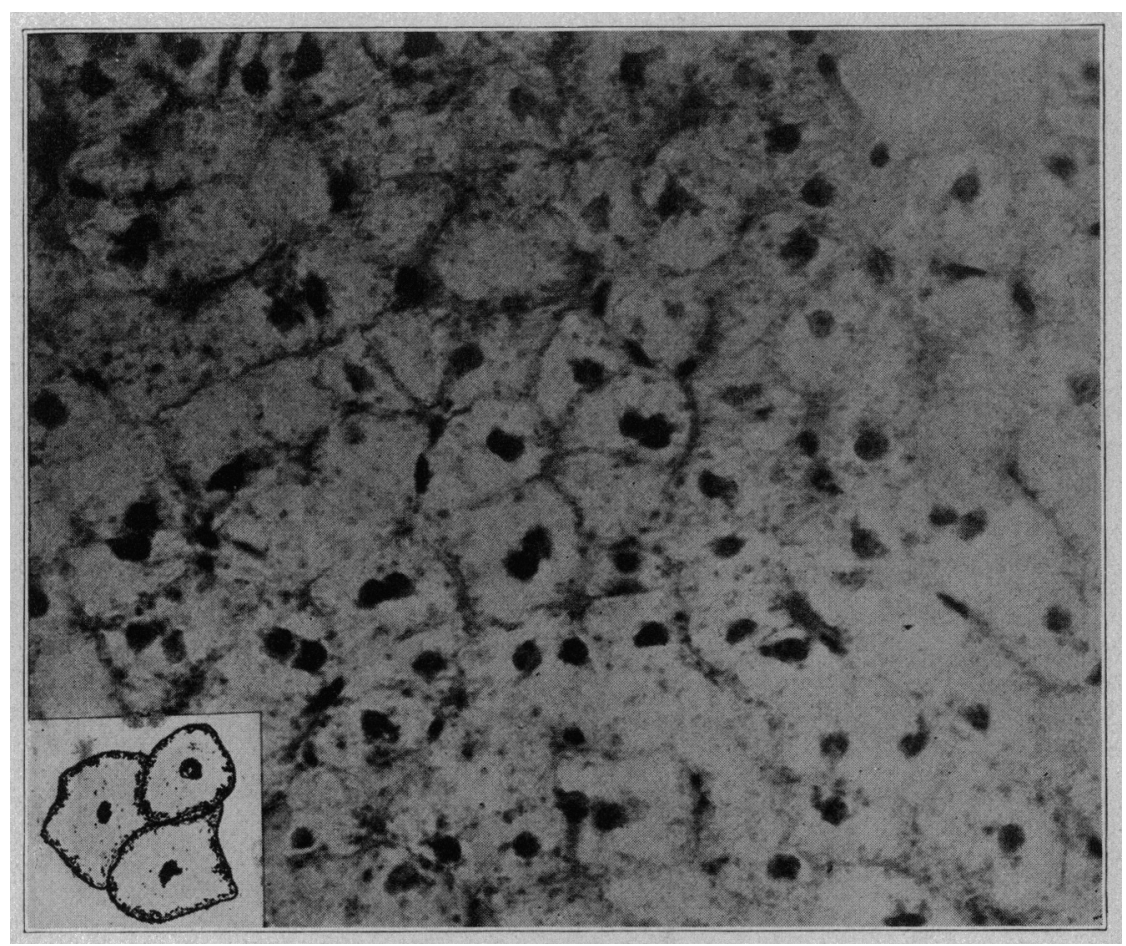

Fig. 7 (Rabi) it 11).-Section showing degenerative changes in the cytoplasm of the liver cells. 
cytoplasm within the cell. Nuclei, many show pyknotic changes. Sinusoids, difficult to distinguish. The endothelial cells have been pushed together by the enlarged liver cells. Pigment granules not present.

RABBit 9.-Weight, 2,000 gm.; received $0.12 \mathrm{gm}$. quinin (0.06 gm. per kilo); killed twenty-four hours after third injection. Same as Rabbit 8.

RABBIT 10.-Weight, $1,380 \mathrm{gm}$.; received $0.12 \mathrm{gm}$. quinin (0.087 gm. per kilo); killed twenty-four hours after third injection. Cells retain their cordlike arrangement to some extent. Enlarged liver cells, from three to four times normal in size. Cytoplasm, coarse granules beginning to clump at the periphery of the cell. Nuclei, normal. Sinusoids, variable; normal in some places and difficult to distinguish in others. Pigment granules present. Although treatment was the same as in Cases 8 and 9, this liver was not as markedly affected by the quinin.

RABBIT 11 (Fig. 7).-Weight, $1,450 \mathrm{gm}$; received $0.12 \mathrm{gm}$. quinin $(0.082 \mathrm{gm}$. per kilo); killed 120 hours after last injection. No definite cellular arrangement. Enlarged liver cells (compare with Fig. 6). Cytoplasm, coarse granules packed at the periphery of the cells. Nuclei, show pyknotic changes. Sinusoids, not visible due to the enlarged liver cells. Pigment granules, not present.

RABBIT 12.-Weight, $1,640 \mathrm{gm}$.; received $0.12 \mathrm{gm}$. quinin ( $0.073 \mathrm{gm}$. per kilo) ; killed 120 hours after last injection. Same as Rabbit 11.

RABBiт 13.-Weight, $1.720 \mathrm{gm}$.; received $0.12 \mathrm{gm}$. quinin (0.064 gm. per kilo); killed 120 hours after last injection. Same as Rabbit 12.

TABle 1.-Summary of All Protocols

\begin{tabular}{|c|c|c|c|c|c|c|c|c|c|c|}
\hline \multirow{2}{*}{$\begin{array}{l}\text { Anj- } \\
\text { mal } \\
\text { Num- } \\
\text { ber }\end{array}$} & \multirow{2}{*}{$\begin{array}{c}\text { Weight } \\
\text { Oi } \\
\text { Rabbit } \\
\text { Gin. }\end{array}$} & \multicolumn{3}{|c|}{$\begin{array}{c}\text { Injection of } \\
\text { Quinin, } \\
\text { Gm. }\end{array}$} & \multirow{2}{*}{$\begin{array}{c}\text { Total } \\
\text { Amount } \\
\text { Received, } \\
\text { Gm. }\end{array}$} & \multirow{2}{*}{$\begin{array}{l}\text { Inter- } \\
\text { vals } \\
\text { at } \\
\text { Whieh } \\
\text { Quinin } \\
\text { Was } \\
\text { In- } \\
\text { jected, } \\
\text { Hrs. }\end{array}$} & \multirow{2}{*}{$\begin{array}{l}\text { Time of } \\
\text { Sacrifice } \\
\text { of } \\
\text { Animal } \\
\text { ifter } \\
\text { Iast } \\
\text { Injec- } \\
\text { tion, } \\
\text { Hrs. }\end{array}$} & \multirow{2}{*}{$\begin{array}{c}\text { 'Total } \\
\text { Amount } \\
\text { of } \\
\text { Quinin } \\
\text { per } \\
\text { Kilo } \\
\text { Body } \\
\text { Weight, } \\
\text { Gill. }\end{array}$} & \multirow{2}{*}{$\begin{array}{c}\text { Corre- } \\
\text { smoniling } \\
\text { Dosage } \\
\text { for } \\
\text { Man } \\
\text { of } \\
\text { tio Lbs. } \\
(\text { tir Kilos) } \\
\text { Gm }\end{array}$} & \multirow[t]{2}{*}{ Comment } \\
\hline & & $1 \mathrm{st}$ & $2 d$ & $3 d$ & & & & & & \\
\hline I & 1,90 & $\ldots$ & $\cdots$ & $\ldots$ & $\cdots$ & . & $\ldots$ & $\ldots \ldots$ & $\ldots$ & $\begin{array}{c}\text { Normal con- } \\
\text { trol }\end{array}$ \\
\hline 2 & 1,$8 ; 0$ & $\ldots$ & $\cdots$ & $\cdots$ & $\ldots$ & $\cdots$ & $\ldots$ & $\ldots$. & $\ldots$ & $\begin{array}{l}\text { Normal con- } \\
\text { trol }\end{array}$ \\
\hline 3 & 1,680 & 0.13 & $\ldots$ & $\ldots$ & 0.13 & $\ldots$ & $1 / 2$ & 0.079 & 5.293 & No reaction \\
\hline 4 & $1,8 \% 0$ & 0.06 & $\cdots$ & $\cdots$ & $0.0 \%$ & $\cdots$ & 24 & $0.03 i$ & 2.479 & $\begin{array}{l}\text { Mild reaction: } \\
\text { recovery in } \\
\text { minutes }\end{array}$ \\
\hline 5 & 2,260 & 0.18 & $\cdots$ & $\ldots$ & 0.18 & . & 24 & 0.079 & 5. 293 & $\begin{array}{l}\text { Mild reaction: } \\
\text { recovery in } 7 \\
\text { minutes }\end{array}$ \\
\hline 6 & 2,140 & 0.06 & $\ldots$ & $\ldots$ & 0.06 & $\ldots$ & 48 & 0.1728 & 1.876 & $\begin{array}{l}\text { Mild reaction: } \\
\text { recovery in } \\
\text { minutes }\end{array}$ \\
\hline 7 & 1.890 & $0.0 \%$ & & & $0.0 \mathrm{r}$ & & 96 & 0.034 & 2.479 & No reaction \\
\hline 8 & 1,800 & 0.06 & 0.04 & 0.04 & 0.14 & 24 & 24 & $0.0 \div 7$ & 5.159 & No reaction \\
\hline 9 & 2,000 & 0.04 & 0.04 & 0.114 & $0.1 ?$ & 24 & 24 & 0.06 & 4.02 & No reaction \\
\hline 10 & 1,380 & 0.04 & 0.04 & 0.04 & 0.72 & 24 & 24 & $0.08 \bar{i}$ & 5.829 & No reaction \\
\hline 11 & $1.450)$ & 0.045 & 0.06 & $\ldots$ & $0.1 . \overline{2}$ & 96 & 120 & 0.082 & 5.494 & No reaction \\
\hline 12 & 1,640 & 0.06 & 0.06 & $\ldots$ & $0.1 ?$ & 96 & 120 & 0.173 & 4891 & No reaction \\
\hline 13 & $1,7 \geq 0$ & 006 & 0.06 & $\ldots$ & 0.12 & 96 & 120 & 0.064 & 4.288 & No reaction \\
\hline
\end{tabular}

\section{DISCLSSION}

One intravenous injection of quinin hydrochlorid produced a gradual progressive change in the liver tissue, followed by a slow recovery. At first, there is noted more or less marked active hyperemia. Within twenty-four hours, the liver cells show some mild hydropic changes in the cytoplasm. In forty-eight, this has progressed to a fatty degen- 
eration of the cytoplasm. Apparently, this is the end result and repair commences to take place. Ninety-six hours after the injection, the liver is practically normal again, as far as we can determine.

However, when the animal receives more than one injection of quinin hydrochlorid, the effect is much more severe. The liver cell enlarges and become three or four times the size of the normal cell. All definite cellular arrangement is lost. Cytoplasmic changes are very marked, resembling a granular degeneration. Even the nuclei are affected and pyknosis is common. Sinusoids cannot be made out in many of the sections. The poor blood supply which the cells consequently receive may account for some of the degenerative changes. It is to be noticed that injection of quinin at twenty-four and ninetysix hour intervals apparently gives much the same result.

Quinin hydrochlorid administered intravenously in moderate doses to healthy rabbits produces degenerative changes in the cellular elements of the liver.

\section{EFFECT OF QUININ ON THE NUMBER OF BLOOD CORPUS- CLES PER CUBIC MILLIMETER}

Material and Method.-For these experiments rabbits 7, 8, 9 and 10 were used. Amounts of quinin injected are listed in Table 1. Red and white cell counts were made immediately before and 24 hours after injection of quinin, except rabbit 7 , on which counts were made five, twenty-four and ninety-six hours after injection. A differential count was made before and after injection, but there were no variations from the normal and details are therefore omitted from this report. (Table 2).

TABle 2.--Effect of Quinin on Blood Cell Count

\begin{tabular}{|c|c|c|c|c|c|c|}
\hline \multirow{2}{*}{$\begin{array}{l}\text { Rabbit } \\
\text { Number }\end{array}$} & \multirow{2}{*}{$\begin{array}{l}\text { Dose per } \\
\text { Kilo, Gm. }\end{array}$} & \multirow{2}{*}{$\begin{array}{l}\text { Corpus- } \\
\text { cles }\end{array}$} & \multicolumn{4}{|c|}{ Blood Counts } \\
\hline & & & $\begin{array}{l}\text { Before } \\
\text { Injection }\end{array}$ & & After Injection & \\
\hline 7 & 0.037 & $\begin{array}{c}\text { Red } \\
\text { White }\end{array}$ & $\begin{array}{r}4,088,000 \\
4,7 \div 5\end{array}$ & $\begin{array}{c}5 \text { hrs. after } \\
6,032,000 \\
8,300\end{array}$ & $\begin{array}{c}24 \text { hrs. after } \\
6,200,000 \\
5,960\end{array}$ & $\begin{array}{c}96 \text { hrs. after } \\
5,456, \mathrm{c00} \\
10,158\end{array}$ \\
\hline 8 & 0.077 & $\begin{array}{c}\text { Red } \\
\text { White }\end{array}$ & $\begin{array}{r}6,090,000 \\
5,275\end{array}$ & $\begin{array}{c}24 \text { hrs. after } \\
\text { 1st injection } \\
8,080,000 \\
7,325\end{array}$ & $\begin{array}{c}24 \text { hrs. after } \\
\text { 2d injection } \\
7,970,000 \\
7,000\end{array}$ & $\begin{array}{c}24 \text { hrs. after } \\
3 \mathrm{~d} \text { injection } \\
7,250,000 \\
3,000\end{array}$ \\
\hline 9 & 0.06 & $\begin{array}{c}\text { Red } \\
\text { White }\end{array}$ & $\begin{array}{r}5,02 \cdot, 000 \\
3,2 \div 6\end{array}$ & $\begin{array}{r}6,320,000 \\
4,075\end{array}$ & $\begin{array}{r}6.0644,000 \\
4,880\end{array}$ & \\
\hline 10 & 0.087 & $\begin{array}{c}\text { Red } \\
\text { White }\end{array}$ & $\begin{array}{r}4,728,000 \\
5,900\end{array}$ & $\begin{array}{r}5,176,000 \\
6,625\end{array}$ & $\begin{array}{r}5,980,000 \\
6,100\end{array}$ & \\
\hline
\end{tabular}

Summary.-Within five hours after an injection of quinin we observe an increase in the number of blood cells per cubic millimeter. The increase in leukocytes is nearly proportional to the increase in red 
blood cells, as would probably be the case if the polycythemia were due only to a loss of plasma. In spite of the changes observed in the liver, there is no change in the differential count of the leukocytes. This is persistent for the next twenty-four hours, and then declines, so that ninety-six hours after the injection the count approaches the normal. However, after repeated injections the blood count remains high.

\section{EFFECT OF QUININ ON THE URINE OUTPUT OF RABBITS}

Rabbits 11, 12 and 13 were used. Details of injection were as shown in Table 1 . The animals were fed and watered routinely. They were placed in separate cages especially constructed to facilitate the collection of urine with very little loss or evaporation. The urine of each animal was collected for four successive days before the injection then for four successive days after the first injection and for five successive days after the second injection (Table 3 ).

TABLE 3.-EFFECT OF QUinin ON URINE OUtPut

\begin{tabular}{|c|c|c|c|c|c|c|c|c|}
\hline \multirow{2}{*}{ Time } & \multirow{2}{*}{$\begin{array}{c}\text { Number } \\
\text { of } \\
\text { Rabbit }\end{array}$} & \multicolumn{5}{|c|}{ Amount of Urine, C.c. } & \multirow{2}{*}{$\begin{array}{c}\text { Total, } \\
\text { C.c. }\end{array}$} & \multirow{2}{*}{$\begin{array}{c}\text { Aver- } \\
\text { age, } \\
\text { C.e. }\end{array}$} \\
\hline & & $\begin{array}{l}\text { 1st } \\
\text { Day }\end{array}$ & $\begin{array}{c}2 d \\
\text { Day }\end{array}$ & $\begin{array}{c}3 \mathrm{~d} \\
\text { Day }\end{array}$ & $\begin{array}{l}\text { 4th } \\
\text { Day }\end{array}$ & $\begin{array}{c}\text { 5th } \\
\text { Day }\end{array}$ & & \\
\hline $\begin{array}{l}\text { Before injection....... } \\
\text { After 1st injection..... } \\
\text { After } 2 d \text { injection..... }\end{array}$ & $\begin{array}{l}11 \\
\cdots \\
\cdots\end{array}$ & $\begin{array}{l}235 \\
386 \\
376\end{array}$ & $\begin{array}{l}212 \\
355 \\
380\end{array}$ & $\begin{array}{l}212 \\
320 \\
280\end{array}$ & $\begin{array}{l}260 \\
288 \\
270\end{array}$ & $\dddot{\cdots}$ & $\begin{array}{r}949 \\
1,349 \\
1,581\end{array}$ & $\begin{array}{l}237 \\
339.6 \\
316\end{array}$ \\
\hline $\begin{array}{l}\text { Before injection........ } \\
\text { After } 1 \text { st injection..... } \\
\text { After } 2 \mathrm{~d} \text { injection...... }\end{array}$ & $\begin{array}{l}12 \\
\cdots \\
\cdots\end{array}$ & $\begin{array}{l}236 \\
400 \\
440\end{array}$ & $\begin{array}{l}190 \\
355 \\
312\end{array}$ & $\begin{array}{l}230 \\
330 \\
.218\end{array}$ & $\begin{array}{l}230 \\
340 \\
208\end{array}$ & $\ddot{2} 36$ & $\begin{array}{r}836 \\
142 \\
1,414\end{array}$ & $\begin{array}{l}221.5 \\
373 \\
283\end{array}$ \\
\hline $\begin{array}{l}\text { Before injection....... } \\
\text { After } 1 \text { st injection..... } \\
\text { After } 2 d \text { injection...... }\end{array}$ & $\begin{array}{l}13 \\
\cdots \\
\cdots\end{array}$ & $\begin{array}{l}160 \\
180 \\
176\end{array}$ & $\begin{array}{l}155 \\
190 \\
140\end{array}$ & $\begin{array}{l}124 \\
196 \\
138\end{array}$ & $\begin{array}{r}206 \\
276 \\
\text { died }\end{array}$ & $\begin{array}{l}\cdots \\
\cdots\end{array}$ & $\begin{array}{l}645 \\
892 \\
454\end{array}$ & $\begin{array}{l}161.2 \\
297 \\
151\end{array}$ \\
\hline
\end{tabular}

Injection of quinin into rabbits produces an immediate and considerable increase in the output of urine. This persists for a day or two and gradually decreases. Repetition of the injection produced a similar effect.

SUMMARY

Quinin hydrochlorid, administered intravenously, in moderate doses, to healthy rabbits, apparently produces the following results :

1. Progressive degenerative changes in the liver cells which increase with increasing dosage.

2. A moderate transitory polycythemia rendered persistent by repeated dosage.

3. Polyuria.

We wish to express our thanks to Dr. A. D. Hirschfelder, Director of the Department of Pharmacology, for helpful suggestions and criticism during the progress of this work. 